\title{
DIFFICULTIES ENCOUNTERED BY NURSE STUDENTS WHEN WORKING WITH ELDERLY PEOPLE
}

\author{
Albena Andonova ${ }^{1}$, Mima Nikolova $^{2}$, Silviya Kyuchukova $^{3}$, Koni Ivanova ${ }^{4}$
}

\begin{abstract}
During the training process, nurse students acquire knowledge, skills and competencies to work with different groups of patients. Working with elderly people has its difficulties and specificities. The acquisition of practical skills by students for planning and documenting individual health care for the elderly people is a process in which teachers and mentors have a leading role.

Objectives: To identify the factors which make it difficult for nurse students to work with elderly people.

Methods: The study involved 52 3rd year nurse students - from the Faculty of Medicine of Trakia University in Bulgaria.

A questionnaire was used, including open-ended and closed-ended questions, allowing more than one answer. The data was processed mathematically and graphically.

Results: The main difficulties for students in working with the elderly people are as follows: the process of communication (92.16\%), difficult perception of new information (80.64\%) and memory impairment in the elderly patient $(61.44 \%)$; The main difficulties related to the organization of activity - insufficient experience in working with geriatric patients $(92.16 \%)$; insufficient time for communication with patients (94.08\%); lack of comfort in the patient's home (57.60\%); a "Diary for tracking and self-monitoring of the condition" of an elderly person - it is very useful for $90.24 \%$ of students so that they can monitor the condition of the elderly person; It was found that $65.28 \%$ of students do not want to work with elderly people, as $46.09 \%$ of them indicate the motive for this as mental strain.

Conclusion: The teacher and the mentor are leading figures in preparing students to work with elderly people. The practical preparation for planning and documenting individual health care for elderly people is very important in the training process of nurse students.
\end{abstract}

UDC Classification: 614.2, DOI: https://doi.org/10.12955/pmp.v2.161

Keywords: nurse students, difficulties, practical training, elderly people, teacher, mentor.

\section{Introduction}

The increase in the elderly population in recent decades has become a challenge for the health systems of EU Member States. At the end of 2019 the population of the Republic of Bulgaria was 6,951,482 people; the Catholic population, aged 65 and over were 1,504,088, or $21.6 \%$ of the country's population (NSI, 2019).

Providing health care to elderly people requires an increase in financial resources, as well as providing trained medical professionals to work with them.

It is necessary to create and implement an integrated model for providing affordable, continuous, sustainable quality health and social care for elderly people (Popova et al., 2017).

Nurses have the knowledge, skills and competence to provide health care for people with different needs, including elderly ones. ${ }^{1}$

During their training, nurses have profiling disciplines where they study the specifics of working with elderly people. During their academic practice and undergraduate internship, students have the opportunity to apply practically the theoretical knowledge acquired during their training. The academic practice of students is managed by teachers and mentors with nursing specialties.

The teacher and the mentor have leading roles in practical training of nurses for the successful application of theoretical knowledge in the work environment and for successful professional preparation (Dragusheva et al., 2019; Santa De et al., 2016; Terzieva et al., 2019).

Assimilating the rules of professional ethics, communication with the patient, and cooperation between staff and the student in planning patient care motivates students and is coordinated by teachers and mentors (Sadeghianetal, 2016; Pedersenetal, 2012).

\footnotetext{
${ }^{1}$ Trakia University, Faculty of Medicine, Department of Health Care, albena.andonova@trakia-uni.bg, ORCID: 0000-0001-7556-321X

2 Trakia University, Faculty of Medicine, Department of Health Care, mima.nikolova@trakia-uni.bg

${ }^{3}$ Trakia University, Faculty of Medicine, Department of Health Care, silviya.kyuchukova@trakia-uni.bg

${ }^{4}$ Trakia University, Faculty of Medicine, Department of General and Clinical Pathology,

koni_ivanova@yahoo.com
} 
Mentors sometimes do not devote enough time to students, and this affects students' practical preparation (Karadağet al., 2013).

Nurse teachers have an important role in encouraging students to work with elderly people after graduation and to change their negative attitudes towards working with elderly people (Mattosetal, 2015).

Providing qualified health care for elderly people is a fundamental goal of health systems. It is very important students be encouraged during their training process to work with elderly people and to conduct research, in order to increase the motivation of nurses to work with geriatric patients (Abreu, et al., 2015).

The negative attitude of students towards working with this group of patients is a reality. Therefore, programs should be developed to stimulate the interest of future nurses to work with elderly people. (Celik et al., 2015; Rodgers et al., 2011; Suikkala et al., 2016).

\section{Objectives}

To identify the factors which make it difficult for nurse students to work with elderly people.

\section{Methods}

The study involved 52 3rd year nurse students from the Medical Faculty of Thracian University in Bulgaria.

The questionnaire that was used included open-ended and closed-ended questions, allowing more than one answer. The data was processed mathematically and graphically.

The research project № 13/2018 at the Trakia University - Stara Zagora, Bulgaria, entitled: "Optimizing the care of the elderly people at home by introducing a 'Diary for tracking and selfmonitoring of the condition' aims to increase students' preparation for working with elderly people. The diary contains forms for daily registration of blood pressure, pulse, glucose, medical therapy, diet (number of meals, type of food, water intake), physical activity, sleep, relaxing and social contacts.

The practical training of the students was conducted by 4 teachers and 8 mentor-nurses working in outpatient care.

The data was processed mathematically and graphically. The project aims to increase the preparation of students for working with elderly people.

\section{Results}

The study found that during academic practice, students collide with a number of difficulties in working with elderly people. The respondents indicate that their main difficulties are related to communication with the elderly people and that they feel mentally burdened after working with elderly patients. The students say that they often encounter difficulties when they are explaining to elderly patients how to take their medications, what changes they need to make in their diet (reduction, increase or prohibition of certain foods and beverages) and in their physical activity (duration of walking, gymnastics, gardening).

\begin{tabular}{|l}
\hline Table 1: Difficulties which students face in working with elderly people \\
$\qquad$\begin{tabular}{|l|c|c|}
\hline \multicolumn{1}{|c|}{ Difficulties } & Students/n & $\%$ \\
\hline $\begin{array}{l}\text { Daily communication with elderly } \\
\text { people }\end{array}$ & 48 & 92.16 \\
\hline $\begin{array}{l}\text { Explaining the medical therapy } \\
\text { change }\end{array}$ & 36 & 69.12 \\
\hline $\begin{array}{l}\text { Explaining the physical activity } \\
\text { change }\end{array}$ & 24 & 46.09 \\
\hline Explaining the diet change & 18 & 34.56 \\
\hline
\end{tabular} \\
\hline
\end{tabular}

According to the respondents, the main problems they encounter in working with elderly people, are related to the difficult perception of new information by the elderly patient $(80.64 \%, n=42)$, slow movements when walking, getting up, eating $(40.32 \%, \mathrm{n}=21)$, decreased sense of touch and pressure which quite often is the cause of injuries in daily activities at home $(38.4 \%, \mathrm{n}=20)$ and memory impairment $(61.44 \%, \mathrm{n}=32)$. 


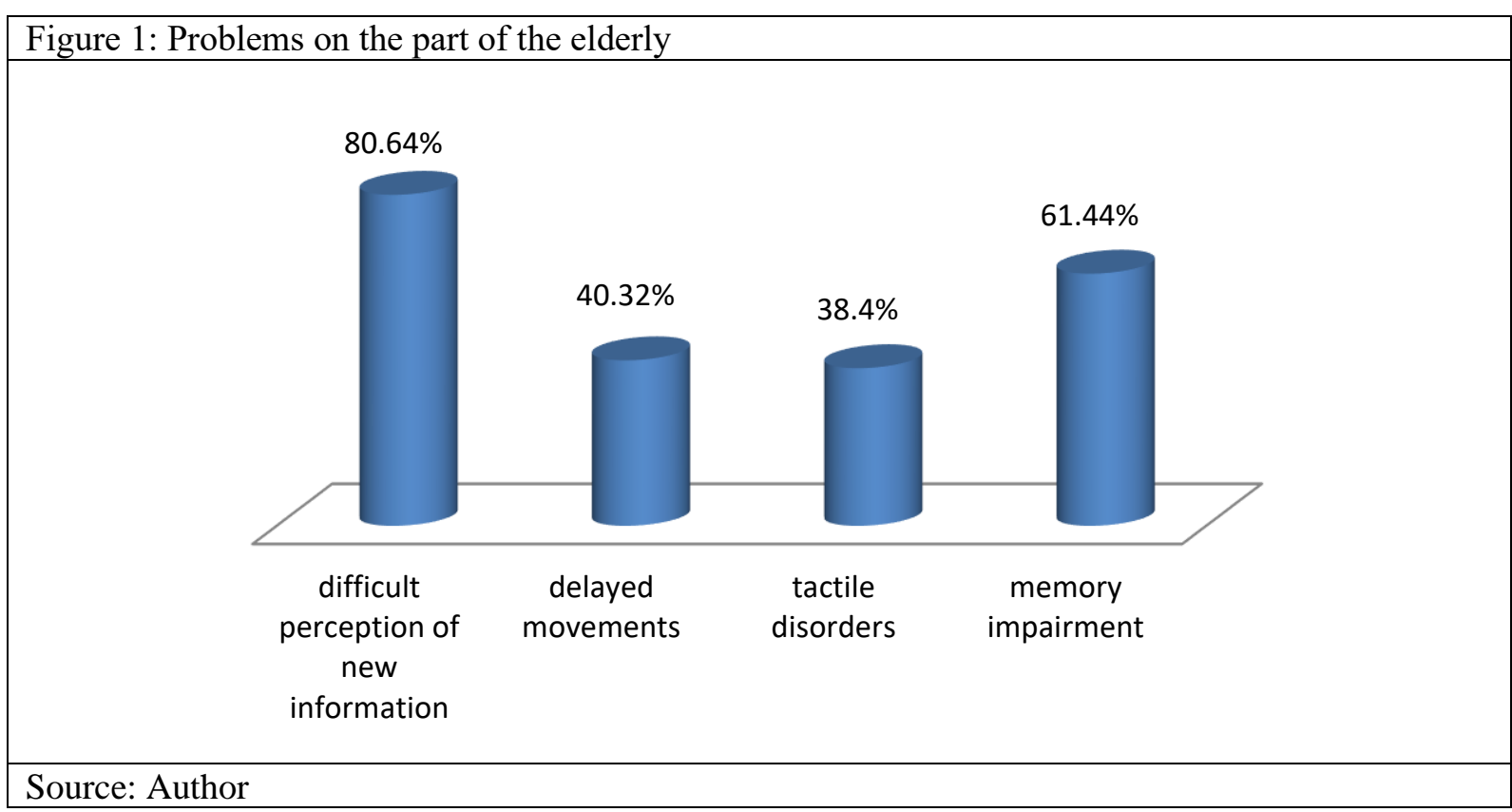

The surveyed students also indicate other complicating factors accompanying the care for the elderly people - insufficient time for communication with patients $(94.08 \%, \mathrm{n}=49)$, lack of comfort in the patient's house $(57.60 \%, \mathrm{n}=30)$, insufficient practical experience of students in working with geriatric patients $(92.16 \%, \mathrm{n}=48)$.

\begin{tabular}{|l}
\hline Figure 2: Factors complicating the care of the elderly patients according to students \\
insufficient student experience \\
lack of amenities in the adult's home \\
insufficient time to communicate with \\
patients
\end{tabular}

All surveyed students say that support from teachers is the most useful for them, because their help gives them the opportunity to get to know the patient, to observe the individual approach and the method of communication of teachers with patients.

Students state that recording the patient information related to medical intake, arterial pressure, diet and physical activity in a "Diary for tracking and self-monitoring of the condition" helps them to analyze the patient's status, to plan individual care, and also to consult with the teacher or mentor. The diary, according to $90.24 \%(\mathrm{n}=47)$ of the students is very useful in monitoring the patient's status and in planning and organizing individual health care.

Students were also asked if they would work with geriatric patients. Unfortunately, only $21.12 \%(\mathrm{n}=$ 11) expressed a desire to work with elderly people. These results are confirmed by Fernandes et al. (2018).

The number of students $65.28 \%(\mathrm{n}=34)$ who definitely do not want to work with elderly people in the future is significant, and the rest indicated the answer "I have not decided yet". When asked why they do not want to work with this group of patients, $46.09 \%(n=24)$ state that they feel mental strain. 


\section{Conclusion}

The main difficulties for students in working with elderly people are as follows: the process of communication $(92.16 \%)$, difficult perception of new information $(80.64 \%)$ and memory impairment in elderly patients $(61.44 \%)$.

The main difficulties related to the organization of activities - insufficient experience in working with geriatric patients $(92.16 \%)$; insufficient time for communication with patients $(94.08 \%)$; lack of comfort in the patient's home $(57.60 \%)$. "Diary for tracking and self-monitoring of the condition" of an elderly person - for $90.24 \%$ of students is very useful in helping them monitor the condition of an elderly person. It was found that $65.28 \%$ of students do not want to work with elderly people, as $46.09 \%$ of them indicate the reason for this as mental strain.

Teachers and mentors take an active part in the practical training of students for overcoming difficulties in working with elderly people. Improving the organization of activities in providing elderly people with health care will motivate students to work with them in the future.

\section{References}

Abreu, M., \& Caldevilla, N. (2015). Attitudes toward Aging in Portuguese Nursing Students. Procedia - Social and Behavioral Sciences, 171, 961-967. https://doi.org/10.1016/j.sbspro.2015.01.215

Celik, S. S., Kapucu, S., Tuna, Z., \& Akkus, Y. (2010). Views and attitudes of nursing students towards ageing and older patients. Australian Journal of Advanced Nursing, The, 27(4), 24. Retrieved February 10, 2021, https://www.ajan.com.au/archive/Vol27/27-4_SenoCelick.pdf

Dragusheva, S., Petleshkova, P., Paskaleva, T., \& Tornyova, B. (2019). Profesionalnite vzaimootnosheniya mezhdu nastavnitsi i stazhant-meditsinski sestri-predpostavka za uspeshnoto provezhdane na preddiplomniya stazh. [The professional realtions between the mentor and the trainee nurses - precondition for succesful implementation of the pre-graduation traineeship]. Management \& Education/Upravlenie i Obrazovanie, 15(5). Retrieved February 10, 2021, from http://www.conference-burgas.com/maevolumes/vol15/b5_v15.pdf

Fernandes, C. S. N. D. N., Afonso, A., \& Couto, G. (2018). Atitudes dos estudantes de enfermagem em relação à pessoa idosa [Nursing students' attitudes toward older people]. Geriatrics, Gerontology and Aging, 12(3), 166-171. Retrieved February 10, 2021, from http://ggaging.com/details/483/en-US/atitudes-dos-estudantes-de-enfermagem-em-relacao-a-pessoaidosa

Karadăg, G., Kayaaslan, H., Kılıç, S.P., Ovayolu, N., \& Ovayolu, Ö. (2013). Difficulties Encountered by Nursing Students in Practices and Their Views about Nurses. TAF Preventive Medicine Bulletin, 12, 665-672. http://dx.doi.org/10.5455/pmb.11353569323

Mattos, M. K., Jiang, Y., Seaman, J. B., Nilsen, M. L., Chasens, E. R., \& Novosel, L. M. (2015). Baccalaureate Nursing Students' Knowledge of and Attitudes Toward Older Adults. Journal of gerontological nursing, 41(7), 46-56. https://doi.org/10.3928/00989134-20150429-01

Mohammadi, N., Bigmoradi, A., \& Hassan Tehrani, T. (2016). Goal achievement in nursingclinical education and effective factors. Avicenna Journal of Nursing and Midwifery Care, 24(3), 138-147. http://dx.doi.org/10.21859/nmj-24031

Pedersen, B., \& Sivonen, K. (2012). The impact of clinical encounters on student nurses' ethical caring. Nursing ethics, 19(6), 838-848. https://doi.org/10.1177/0969733012447017

Popova, K., \& Terzieva, G. (2017). Geriatric care - necessity and tendencies. Knowledge International Journal, 17(3), 1155 1161. Retrieved February 10, 2021, from http://www.ikm.mk/ojs/index.php/KIJ/article/view/4468

Rodgers, V., \& Gilmour, J. (2011). Shaping student nurses' attitudes towards older people through learning and experience. Nursing praxis in New Zealand inc, 27(3), 13-20. Retrieved February 10, 2021, from https://pubmed.ncbi.nlm.nih.gov/22375376/

Santa De, P. M., \& Bera, L. P. (2016). Nursing student's clinical learning experiences and the barriers faced. International editorial advisory board, 8(2), 169. http://dx.doi.org/10.5958/0974-9357.2016.00070.2

Suikkala, A., Kivelä, E., \& Käyhkö, P. (2016). Collaborative learning in gerontological clinical settings: The students' perspective. Nurse education in practice, 17, 229-234. https://doi.org/10.1016/j.nepr.2016.02.006

Terzieva, G., \& Popova, K. (2019). Nursing students` training in geriatric care challenges, reality, TRENDS. Knowledge International Journal, 26(4), 1097 - 1103. Retrieved February 10, 2021, from https://ikm.mk/ojs/index.php/KIJ/article/view/599

NSI. Naselenie i demografski protsesi prez 2019 godina, (2019). [Population and demographic processes in 2019]. Retrieved February 10, 2021, from https://www.nsi.bg/sites/default/files/files/pressreleases/Population2019_XE8MEZL.pdf 